\title{
PTPN2 Gene
}

National Cancer Institute

\section{Source}

National Cancer Institute. PTPN2 Gene. NCI Thesaurus. Code C138101.

This gene is involved in the dephosphorylation of receptor tyrosine kinases. 